\title{
PERIODONTAL DISEASE IN DIFFERENT STAGES OF CHRONIC KIDNEY DISEASE
}

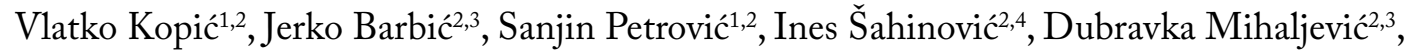 \\ Andrijana Kopić, ${ }^{2,5}$ and Andrija Bošnjak ${ }^{2,6,7}$
}

${ }^{1}$ Department of Maxillofacial and Oral Surgery, Osijek University Hospital Centre, Osijek, Croatia;

${ }^{2}$ School of Medicine, Josip Juraj Strossmayer University of Osijek, Osijek, Croatia;

${ }^{3}$ Department of Nephrology and Dialysis, Osijek University Hospital Centre, Osijek, Croatia;

${ }^{4}$ Department of Clinical Laboratory Diagnostics, Osijek University Hospital Centre, Osijek, Croatia;

${ }^{5}$ Department of Ophthalmology, Osijek University Hospital Centre, Osijek, Croatia;

${ }^{6}$ Department of Oral Medicine and Periodontology, School of Medicine, University of Rijeka, Rijeka, Croatia;

${ }^{7}$ Department of Oral Medicine and Periodontology, School of Medicine, University of Split, Split, Croatia

SUMMARY - Periodontal disease is a chronic multifactorial disease the worldwide incidence of which is higher than the incidence of caries and represents one of the leading problems in dental medicine. It is manifested by the loss of the attachment apparatus of the tooth and leads to the loss of teeth. Numerous studies have shown the association of periodontal disease and various chronic systemic diseases such as diabetes mellitus and cardiovascular disease. It is believed that low-grade level of chronic inflammation and release of bacterial toxins and inflammatory mediators in the bloodstream aggravate a chronic systemic disease. The purpose of our research was to investigate the possible association of periodontal disease and chronic kidney disease via the inflammatory cytokines path. In this cross-sectional study, we surveyed a total of 80 subjects divided into two groups. First group included subjects with chronic renal disease stages III and IV, and the second group included patients with chronic renal disease stage $V$ that were on hemodialysis. We compared periodontal status, as well as serum levels of different cytokines, interleukin 6, interleukin 17A and tumor necrosis factor $\alpha$ between the two groups. The results showed no significant between-group differences in periodontal status, but interleukin 6 levels were significantly higher in the hemodialysis group of patients and were also associated with a poorer periodontal status.

Key words: Periodontal disease; Chronic kidney disease; Hemodialysis; Inflammation; Cytokines

\section{Introduction}

Periodontal disease (PD) can be defined as a chronic, multifactorial, low-grade inflammatory condition ${ }^{1}$. It causes loss of supporting tissues of the tooth and is associated with numerous bacterial species that thrive in the oral biofilm on the surface of the teeth. Although the causes and pathogenesis of PD is an attrac-

Correspondence to: Vlatko Kopic, $M D$, Department of Maxillofacial and Oral Surgery, Osijek University Hospital Centre, Huttlerova 4, HR-31000 Osijek, Croatia

E-mail: kopicv@gmail.com

Received May 8, 2019, accepted May 21, 2019 tive topic and has been thoroughly investigated, an emerging field of research is the association between PD and different systemic disorders and conditions ${ }^{2}$. The most investigated connection is the one between $\mathrm{PD}$ and diabetes mellitus (DM $)^{3,4}$, to the extent that in some instances PD is named as the sixth major complication of $\mathrm{DM}^{5-7}$.

Furthermore, studies have discovered, and to some extent confirmed, the association of PD and cardiovascular disease $^{8}$, chronic obstructive pulmonary disease ${ }^{9}$, rheumatoid arthritis ${ }^{10}$, preterm low birthweight ${ }^{11}$, different types of cancer ${ }^{12}$ and metabolic syndrome. Association of $\mathrm{PD}$ and chronic kidney disease (CKD) 
has not yet been thoroughly explained, but there is some information on the relationship ${ }^{13,14}$.

Considering the fact that bacterial products and inflammatory mediators can access the bloodstream in patients with $\mathrm{PD}$, their immune response is under a constant microbial burden. It has been shown that the chronic low-grade inflammatory condition is one of the main links between PD and systemic diseases and conditions ${ }^{15,16}$.

To help comprehend the possible impact of PD on general health, biomarkers in the serum of individuals with various chronic systemic diseases were investigated. Inflammatory biomarkers such as $\mathrm{C}$-reactive protein (CRP) and different types of cytokines have been shown to have higher serum levels in subjects with PD compared to healthy individuals. Similar results were shown for numerous chronic systemic diseases and $\mathrm{PD}^{17,18}$.

Chronic kidney disease is a severe and irreversible condition that causes destruction of nephrons and loss of normal renal function. The most frequent etiology of CKD includes diabetes mellitus, hypertension, polycystic kidney disease and glomerulonephritis. In terminal stage of $\mathrm{CKD}$, patients need hemodialysis or kidney transplantation. It should be noted that almost all of these patients have a great number of severe systemic comorbidities.

It has been already reported that almost $60 \%$ of patients with $\mathrm{CKD}$ have moderate to severe $\mathrm{PD}^{19}$. PD is also associated with malnutrition. Malnutrition and inflammation are predicting factors for morbidity and mortality in CKD. There are theories suggesting that advanced $\mathrm{PD}$ can aggravate $\mathrm{CKD}$ due to the increased inflammatory response.

The purpose of our study was to investigate the association of PD and different stages of CKD together with the levels of inflammatory biomarkers such as $\mathrm{CRP}$ and some types of cytokines in the bloodstream.

\section{Subjects and Methods}

The study design and protocol were accepted and confirmed by the hospital Ethics Committee. Each patient provided his/her written informed consent for voluntary participation in the study. All patients were regular patients from Department of Nephrology and Dialysis, Osijek University Hospital Centre, Osijek, Croatia.
A total of 80 patients with CKD aged over 18, both male and female, were enrolled in this cross-sectional cohort study and divided into two groups according to the CKD stage. The first group comprised 40 patients with CKD stage $V$ that had been treated with hemodialysis for at least three months (HD group). The second group comprised 40 patients with CKD stages III and IV (control group).

The stage of CKD was calculated with the Modification of Diet in Renal Disease Study (MDRD) equation that estimates glomerular filtration rate based on creatinine and patient characteristics.

Medical history and documentation provided data on $\mathrm{CKD}$, cause of $\mathrm{CKD}$, duration of disease, duration of hemodialysis, comorbidities, body mass, height, body mass index (BMI) and history of smoking.

All patients underwent clinical periodontal examination. We measured plaque and bleeding scores, probing depth and gingival recession (GR). Laboratory data were also collected, including CRP. We also collected blood samples for interleukin 6 (IL-6), interleukin 17A (IL-17A) and tumor necrosis factor $\alpha$ (TNF- $\alpha$ ) that were analyzed at the Department of Clinical Laboratory Diagnostics. All laboratory data on patients treated with hemodialysis were collected before and after dialysis.

All patients with acute progressive glomerulonephritis and other chronic diseases that are treated with corticosteroid and immunosuppressive therapy were excluded from the study. We also excluded patients with malignant diseases that were on some sort of oncology treatment and patients with acute infections. All edentulous patients were also excluded from the study.

\section{Clinical periodontal examination}

Clinical periodontal examination included the following variables: probing depth, GR, Approximal Plaque Index (API) and Papillary Bleeding Index (PBI). Probing depth was measured at six sites of all present teeth by a calibrated periodontal probe (DB 768, Aesculap, Tuttlingen, Germany). All measurements were performed by a single researcher.

\section{Laboratory analysis}

Three biomarkers were assessed in serum. IL-6 (Human IL-6 ELISA, Affymetrix, eBioscinece, USA), 
Table 1. Basic characteristics of patients, inflammatory parameters, cytokines and periodontal status in relation to different stages of chronic kidney disease

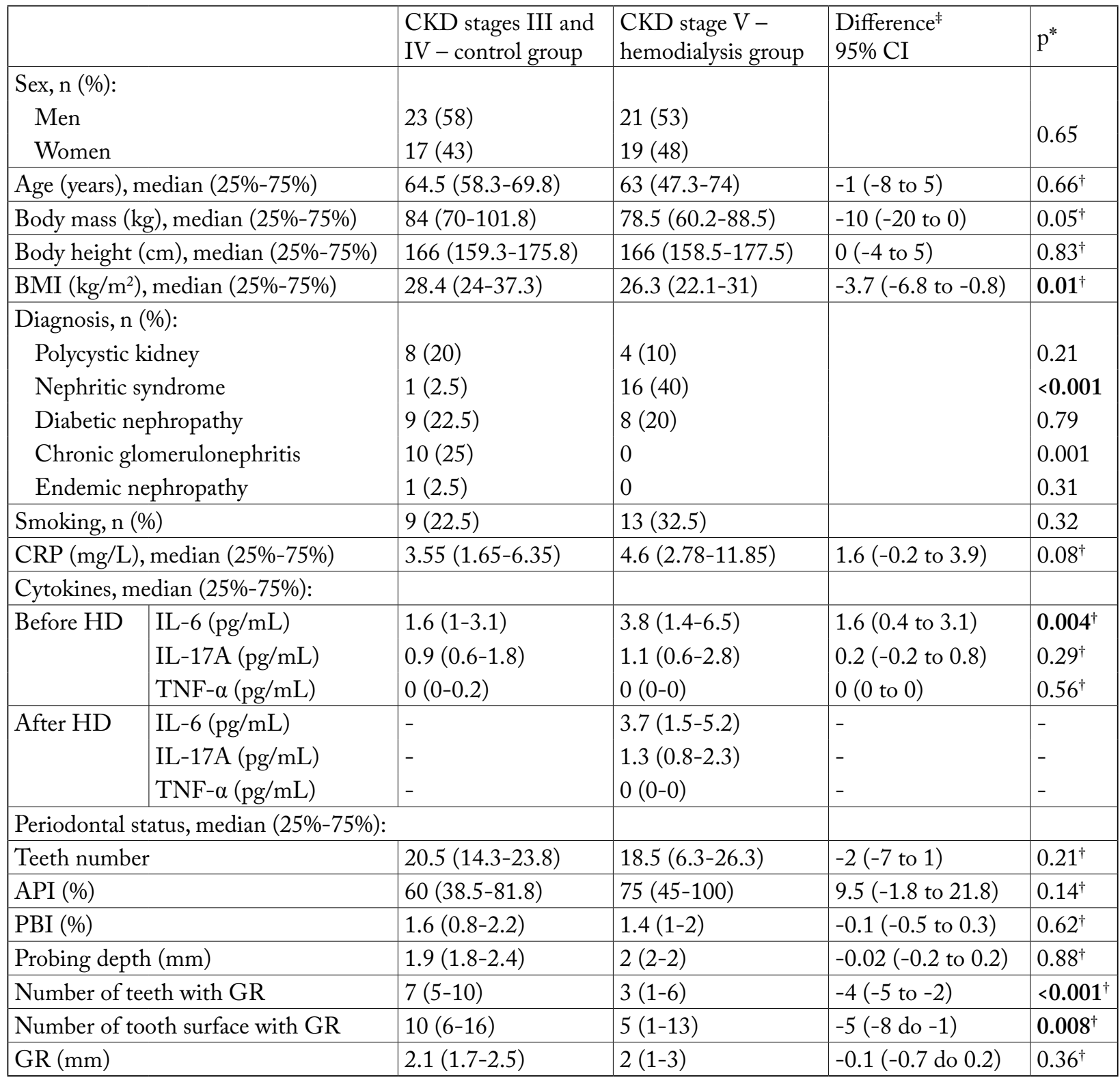

* $\chi^{2}$-test; $†$ Mann Whitney U test; $\neq$ Hodges-Lehmann median difference; $95 \% \mathrm{CI}=95 \%$ confidence interval; $\mathrm{CKD}=$ chronic kidney disease; $\mathrm{BMI}=$ body mass index; $\mathrm{CRP}=\mathrm{C}$-reactive protein; $\mathrm{HD}=$ hemodialysis; $\mathrm{GR}=$ gingival recession; IL-6 = interleukin 6; IL-17A = interleukin $17 \mathrm{~A} ; \mathrm{TNF}-\alpha=$ tumor necrosis factor $\alpha$; API = Approximate Plaque Index; PBI = Papillary Bleeding Index

TNF- $\alpha$ (Human TNF alpha ELISA, Affymetrix, eBioscinece, USA) and IL-17A (Human IL-17A ELISA, Affymetrix, eBioscinece, USA) assays were performed according to the manufacturer's instructions. The limit of detection was $1 \mathrm{pg} / \mathrm{mL}$. Laboratory analysis was conducted at the Department of Clinical Laboratory Diagnostics, Osijek University Hospital Centre.

\section{Statistical analysis}

Category data were represented by absolute and relative frequencies. Variations of category variables were tested by $\chi^{2}$-test. Numerical data were described by median and limits of the interquartile range. The normality of distribution of the observed numerical 
Table 2. Association of cytokine and CRP serum levels with periodontal status

\begin{tabular}{|l|l|l|l|l|}
\hline & \multicolumn{4}{l|}{ Spearman's coefficient of correlation Rho (p value) } \\
\hline Control group: & CRP & IL-6 & IL-17A & TNF- $\alpha$ \\
CKD stages III and IV) & $-0.081(0.62)$ & $-0.061(0.71)$ & $0.079(0.63)$ & $0.147(0.37)$ \\
Number of teeth & $0.167(0.31)$ & $0.506(0.001)$ & $0.030(0.86)$ & $0.031(0.85)$ \\
API (\%) & $0.099(0.55)$ & $0.073(0.66)$ & $0.070(0.67)$ & $-0.156(0.34)$ \\
PBI (\%) & $0.192(0.24)$ & $0.198(0.23)$ & $0.202(0.22)$ & $-0.011(0.95)$ \\
Probing depth (mm) & $-0.014(0.93)$ & $-0.006(0.97)$ & $0.063(0.71)$ & $-0.015(0.93)$ \\
Number of teeth with GR & $-0.013(0.94)$ & $0.106(0.52)$ & $0.006(0.97)$ & $-0.071(0.67)$ \\
Number of tooth surface with GR & $-0.304(0.06)$ & $-0.143(0.39)$ & $-0.061(0.71)$ & $-0.224(0.17)$ \\
GR (mm) & CRP & IL-6 & IL-17A & TNF $\alpha$ \\
\hline HD group: & $-0.264(0.10)$ & $-0.208(0.20)$ & $0.120(0.46)$ & $0.125(0.44)$ \\
CKD stage V (before HD) & $0.072(0.67)$ & $0.255(0.13)$ & $0.278(0.09)$ & $0.241(0.15)$ \\
Number of teeth & $-0.185(0.27)$ & $-0.106(0.53)$ & $0.134(0.43)$ & $0.070(0.68)$ \\
API (\%) & $-0.061(0.72)$ & $0.311(0.06)$ & $0.229(0.17)$ & $0.144(0.40)$ \\
PBI (\%) & $-0.012(0.95)$ & $0.181(0.28)$ & $-0.102(0.55)$ & $-0.029(0.87)$ \\
Probing depth (mm) & $0.079(0.64)$ & $0.264(0.11)$ & $-0.190(0.26)$ & $-0.061(0.72)$ \\
Number of teeth with GR & $-0.005(0.98)$ & $0.156(0.36)$ & $-0.271(0.11)$ & $-0.076(0.66)$ \\
Number of tooth surface with GR & CRP & IL-6 & IL-17A & TNF $\alpha$ \\
GR (mm) & & $-0.112(0.49)$ & $0.165(0.31)$ & $0.087(0.59)$ \\
\hline HD group: & & $0.183(0.28)$ & $0.212(0.21)$ & $0.217(0.20)$ \\
CKD stage V (after HD) & & $-0.100(0.56)$ & $0.235(0.16)$ & $0.004(0.98)$ \\
Number of teeth & $0.366(0.03)$ & $0.284(0.09)$ & $0.195(0.25)$ \\
API (\%) & & $0.270(0.11)$ & $-0.066(0.70)$ & $0.038(0.82)$ \\
PBI (\%) & & $0.189(0.26)$ & $-0.261(0.12)$ & $-0.092(0.59)$ \\
Probing depth (mm) & & & $-0.174(0.30)$ & $0.017(0.92)$ \\
Number of teeth with GR & & & \\
Number of tooth surface with GR & & & \\
GR (mm) & & & \\
\hline
\end{tabular}

$\mathrm{CKD}=$ chronic kidney disease; IL-6 = interleukin 6; IL-17A = interleukin 17A; TNF- $\alpha=$ tumor necrosis factor $\alpha$; API = Approximal Plaque Index; PBI = Papillary Bleeding Index; CRP = C-reactive protein; GR = gingival recession; HD = hemodialysis

variables was tested by the Shapiro-Wilk test. Differences in numerical variables between the two independent groups were tested by Mann-Whitney test (with Hodges-Lehmann median difference and 95\% confidence interval $(95 \% \mathrm{CI}))$. The correlation between variables was assessed by Spearman's correlation coefficient $\rho$ (Rho). All $p$ values were two-sided. The level of significance was set at alpha $=0.05$. Statistical analysis was performed by use of MedCalc Statistical Software version 18.11.3 (MedCalc Software bvba, Ostend, Belgium; https://www.medcalc.org; 2019).

\section{Results}

The study was performed on 80 subjects, 44 (55\%) men and 36 (45\%) women. The mean (median) age of the subjects was 64 years, with the interquartile range from 54 to 71 years. In the group of subjects with CKD stages III and IV (control group), four (10\%) subjects were $\mathrm{CKD}$ stage $3 \mathrm{a}$, seven (17.5\%) CKD stage $3 \mathrm{~b}$ and $29(72.5 \%)$ CKD stage 4 (Table 1$)$.

There was no significant difference between the groups according to body mass and height, whereas BMI was significantly higher in control group (Mann 
Whitney $U$ test, $\mathrm{p}=0.01)$. The most common causes of CKD in both groups were diabetic nephropathy and polycystic kidney disease, whereas nephritic syndrome was significantly more frequent in control group $\left(\chi^{2}\right.$-test, $\left.\mathrm{p}<0.001\right)$. Considering risk factors for PD, there were $22(27.5 \%)$ smokers in both groups. There were no statistically significant differences in CRP $(\mathrm{mg} / \mathrm{L})$ levels between the groups (Table 1).

The levels of IL-6 (pg/mL) prior to dialysis were significantly higher in the hemodialysis group compared to control group (Hodges-Lehmann difference, $1.6 \mathrm{pg} / \mathrm{mL}, 95 \% \mathrm{CI}-0.2 \mathrm{pg} / \mathrm{mL}$ to $3.9 \mathrm{pg} / \mathrm{mL}$; Mann Whitney U test, $\mathrm{p}=0.004$ ), whereas the levels of other two cytokines showed no statistically significant between-group differences (Table 1).

Considering periodontal status, there were no statistically significant differences in the number of retained teeth, API, PBI, probing depth and GR between the groups, whereas the number of teeth with GR was significantly lower in hemodialysis group (Hodges-Lehmann difference $-4,95 \%$ CI -5 to -2 ; Mann Whitney U test, $\mathrm{p}<0.001$ ). The number of tooth surfaces with GR was also significantly lower in hemodialysis patients as compared with control group (Hodges-Lehmann difference $-5,95 \%$ CI -8 to -1 ; Mann Whitney U test, $\mathrm{p}=0.008$ ) (Table 1).

Spearman's coefficient of correlation evaluated the association of CRP and cytokine levels with PD between the groups. Control group patients that had higher serum levels of IL-6 had higher API and vice versa (Spearman's correlation coefficient $\mathrm{Rho}=0.506$; $\mathrm{p}=0.001)$. In the hemodialysis group of patients with chronic renal disease (stage $\mathrm{V}$ ), there was no significant association between CRP and cytokine serum levels with periodontal status. In the same group of patients, higher serum levels of IL-6 after dialysis were associated with higher probing depth and vice versa (Spearman's correlation coefficient $\mathrm{Rho}=0.366$; $\mathrm{p}=0.03$ ) (Table 2).

\section{Discussion}

Periodontal disease is a significant problem in dental medicine because of its high prevalence, especially in older population ${ }^{20,21}$. Theories on additional inflammatory burden that occurs due to PD in patients with chronic systemic diseases have recently been gaining interest ${ }^{22}$.
Trying to improve the quality of life in individuals with chronic diseases, it is important to think of periodontal status and oral health. Earlier studies suggest that chronic diseases and PD affect one another in a way that worsening of one disease means worsening of the other. CKD is a condition that significantly reduces the quality of life of patients, especially in terminal stage when patients end up on hemodialysis ${ }^{23,24}$.

With progression of $\mathrm{CKD}$, there are additional risk factors for worsening of PD because of the endocrinologic disorder, as well as bone metabolism disorder that cannot be replaced by substitution therapy for $\mathrm{CKD}^{25}$. Comorbidities such as DM significantly contribute to worsening of $\mathrm{PD}^{26}$.

Earlier studies have also demonstrated the correlation of CRP levels, as well as of elevated levels of highdensity lipoprotein-cholesterol (HDL-C) and decreased low-density lipoprotein-cholesterol (LDL-C) levels with PD severity ${ }^{27,28}$. However, it is difficult to accurately estimate the effects of particular comorbidities and life habits such as smoking and oral hygiene on worsening of $\mathrm{PD}^{29,30}$. Interleukins are considered to be biomarkers the levels of which increase in various inflammatory conditions.

The results of our research did not show significant difference in periodontal status between the two groups. There are probably several reasons for this, one of them being the fact that the control group comprised subjects with only one to two grades of milder $\mathrm{CKD}$, and this difference may not be sufficient to affect periodontal status significantly ${ }^{31}$.

There was no difference in inflammatory cytokine levels in the HD group of patients before and after hemodialysis.

Of all serum cytokine levels tested, only IL-6 had a statistically significantly higher level in the HD group of patients. IL-17A and TNF- $\alpha$ levels did not show increase in the higher grade of $\mathrm{CKD}^{32}$.

However, even the elevated levels of IL-6 indicate that inflammatory burden can increase with the grade of renal impairment. Particularly encouraging for future researches are our results associating elevated levels of IL-6 with worse periodontal status in the same group of subjects.

Based on these results, we can conclude that it is very important for patients with chronic renal failure, especially those on hemodialysis and maybe waiting for kidney transplantation, to improve their oral hy- 
giene and visit their dentist more frequently in order to prevent possible further deterioration of periodontal status and possibly their general condition.

\section{References}

1. Zekeridou A, Mombelli A, Cancela J, Courvoisier D, Giannopoulou C. Systemic inflammatory burden and local inflammation in periodontitis: what is the link between inflammatory biomarkers in serum and gingival crevicular fluid? Clin Exp Dent Res. 2019 Jan 24;5(2):128-35. doi: 10.1002/cre2.162. eCollection 2019 Apr.

2. John V, Alqallaf H, De Bedout T. Periodontal disease and systemic diseases: an update for the clinician. J Indiana Dent Assoc. 2016;95(1):16-23.

3. Katz PP, Wirthlin M, Szpunar SM, Selby JV, Showstack JA. Epidemiology and prevention of periodontal disease in individuals with diabetes. Diabetes Care. 1991;14(5):375-85.

4. Preshaw PM, Alba AL, Herrera D, et al. Periodontitis and diabetes: a two-way relationship. Diabetologia. 2011;55(1):21-31. doi: 10.1007/s00125-011-2342-y.

5. Grossi SG, Zambon JJ, Ho AW, Koch G, Dunford RG, Machtei EE, et al. Assessment of risk for periodontal disease. Risk indicators for attachment loss.J Periodontol. 1994;65(3):260-7.

6. Löe H. Periodontal disease. The sixth complication of diabetes mellitus. Diabetes Care. 1993;16(1):329-34.

7. Rees TD. The diabetic dental patient. Dent Clin North Am. 1994;38(3):447-63.

8. Montenegro MM, Ribeiro IWJ, Kampits C, Saffi MAL, Furtado MV, Polanczyk CA, Haas AN, Rösing CK. Randomized controlled trial of the effect of periodontal treatment on cardiovascular risk biomarkers in patients with stable coronary artery disease: preliminary findings of 3 months. J Clin Periodontol. 2019 Mar;46(3):321-31. Epub 2019 Mar 6.

9. Spiropoulou A, Zareifopoulos N, Bellou A, Spiropoulos K, Tsalikis L. Review of the association between periodontitis and chronic obstructive pulmonary disease in smokers. Monaldi Arch Chest Dis. 2019 Mar 20;89(1). doi: 10.4081/monaldi.2019.1018.

10. Cheng Z, Meade J, Mankia K, et al. Periodontal disease and periodontal bacteria as triggers for rheumatoid arthritis. Best Pract Res Clin Rheumatol. 2017 Feb;31(1):19-30. doi: 10.1016/j.berh.2017.08.001. Epub 2017 Sep 1.

11. Daalderop LA, Wieland BV, Tomsin K, et al. Periodontal disease and pregnancy outcomes: overview of systematic reviews. JDR Clin Trans Res. 2017;3(1):10-27. doi: 10.1177/238008 4417731097.

12. Hoare A, Soto C, Rojas-Celis V, Bravo D. Chronic inflammation as a link between periodontitis and carcinogenesis. Mediators Inflamm. 2019 Mar 27;2019:1029857. doi: 10.1155/2019 /1029857. eCollection 2019.

13. Grubbs V, Garcia F, Jue BL, et al. The Kidney and Periodontal Disease (KAPD) study: a pilot randomized controlled trial testing the effect of non-surgical periodontal therapy on chronic kidney disease. Contemp Clin Trials. 2016;53:143-50. doi: 10.1016/j.cct.2016.12.017.

14. Ricardo AC, Athavale A, Chen J, et al. Periodontal disease, chronic kidney disease and mortality: results from the Third National Health and Nutrition Examination Survey. BMC Nephrol. 2015;16:97. Published 2015 Jul 7. doi: 10.1186/ s12882-015-0101-x.

15. Buduneli N, Kinane DF. Host-derived diagnostic markers related to soft tissue destruction and bone degradation in periodontitis. J Clin Periodontol. 2011;38(Suppl. 11):85-105. doi: 10.1111/j.1600-051X.2010.01670.x.

16. Schenkein HA, Loos BG. Inflammatory mechanisms linking periodontal diseases to cardiovascular diseases. J Clin Periodontol. 2013;40 Suppl 14(0 14):S51-S69. doi: 10.1111/jcpe. 12060 .

17. Bretz WA, Weyant RJ, Corby PM, Ren D, Weissfeld L, et al. Systemic inflammatory markers, periodontal diseases, and periodontal infections in an elderly population. J Am Geriatr Soc. 2005 Sep;53(9):1532-7.

18. Puhar I, Lovrencić-Huzjan A, Plančak D, Sodec-Simičević D, Strineka M, Demarin V. Internal carotid occlusion in a patient with previous history of periodontitis: case report. Acta Clin Croat. 2012 Sep;51(3):441-4.

19. Chen LP, Chiang CK, Chan CP, Hung KY, Huang CS. Does periodontitis reflect inflammation and malnutrition status in hemodialysis patients? Am J Kidney Dis. 2006;47:815-22.

20. Eke PI, Wei L, Borgnakke WS, Thornton-Evans GO, Zhang $\mathrm{X}, \mathrm{Lu} \mathrm{H}, \mathrm{McGuire} \mathrm{LC}$, Genco RJ. Periodontitis prevalence in adults $\geq 65$ years of age, in the USA. J Periodontol. 2000;72: 76-95. doi: 10.1111/prd.12145.

21. Eke PI, Dye BA, Wei L, Slade GD, Thornton-Evans GO, Borgnakke WS, Taylor GW, Page RC, Beck JD, Genco RJ. Update on prevalence of periodontitis in adults in the United States: NHANES 2009 to 2012. J Periodontol. 2015 May;86:611-22. doi: 10.1902/jop.2015.140520.

22. Landzberg M, Doering H, Aboodi GM, Tenenbaum HC, Glogauer M. Quantifying oral inflammatory load: oral neutrophil counts in periodontal health and disease. J Periodont Res. 2015;50:330-6. https://doi.org/10.1111/jre.12211.

23. Rogan A, McCarthy K, McGregor G, Hamborg T, Evans G, et al. Quality of life measures predict cardiovascular health and physical performance in chronic renal failure patients. PLoS One. 2017 Sep 14;12(9):e0183926. doi: 10.1371/journal. pone.0183926. eCollection 2017.

24. Cabrera VJ, Hansson J, Kliger AS, Finkelstein FO. Symptom management of the patient with CKD: the role of dialysis. CJASN. April 2017;12(4):687-93. Doi: https://doi.org/ 10.2215/CJN.01650216.

25. Lertpimonchai A, Rattanasiri S, Tamsailom S, Champaiboon C, Ingsathit A, Kitiyakara C, Limpianunchai A, Attia J, Sritara $\mathrm{P}$, Thakkinstian A. Periodontitis as the risk factor of chronic kidney disease: mediation analysis. J Clin Periodontol. 2019. Accepted Author Manuscript. doi: 10.1111/jcpe.13114 
26. Ziukaite L, Slot DE, Cobb CM, Coucke W, Van der Weijden GA. Prevalence of diabetes among patients diagnosed with periodontitis: a retrospective cross-sectional study. Int J Dent Hyg. 2018;16:305-11. https://doi.org/10.1111/idh.12280.

27. Webster AC, Nagler EV, Morton RL, Masson P. Chronic kidney disease. Lancet. 2017;389(10075):1238-52.

28. Go AS, Chertow GM, Fan D, McCulloch CE, Hsu CY. Chronic kidney disease and the risks of death, cardiovascular events, and hospitalization. N Engl J Med. 2004;351(13):1296-305.

29. Xia J, Wang L, Ma Z, Zhong L, Wang Y, Gao Y, He L, Su X. Cigarette smoking and chronic kidney disease in the general population: a systematic review and meta-analysis of prospective cohort studies. Nephrol Dial Transplant. 2017 Mar 1; 32(3):475-87. doi: $10.1093 / \mathrm{ndt} / \mathrm{gfw} 452$.
30. Nociti FH Jr, Casati MZ, Duarte PM. Current perspective of the impact of smoking on the progression and treatment of periodontitis. Periodontology 2000. 2015 Feb;67(1):187-210. doi: 10.1111/prd.12063.

31. Zhang D, Liu W, Miao R, Wang L, Zhou X, Wang H, Li Y, Wang Z. Chronic periodontitis is a risk factor of renal dysfunction in patients with type 2 diabetes. Exp Clin Endocrinol Diabetes. 2019 May 2. doi: 10.1055/a-0895-5275. [Epub ahead of print]

32. Thorman R, Lundahl J, Yucel-Lindberg T, Hylander B. Inflammatory cytokines in saliva: early signs of metabolic disorders in chronic kidney disease. A controlled cross-sectional study. Oral Surg Oral Med Oral Pathol Oral Radiol Endod. 2010 Nov;110(5):597-604. doi: 10.1016/j.tripleo.2010.07.007.

Sažetak

\title{
PARODONTNA BOLEST U RAZLIČITIM STADIJIMA KRONIČNE BUBREŽNE BOLESTI
}

\author{
V. Kopic, J. Barbic, S. Petrović, I. Šahinovic, D. Mihaljevic, A. Kopić i A. Bošnjak
}

Parodontna bolest kronična je multifaktorska bolest učestalost koje prema novijim podacima premašuje učestalost karijesa i kao takva predstavlja jedan od vodećih problema u dentalnoj medicini. Uzrokuje gubitak potpornog tkiva zuba i na kraju samog zuba. Brojna istraživanja dokazala su povezanost parodontne bolesti i različitih kroničnih sistemskih bolesti, npr. dijabetesa i kardiovaskularne bolesti. Smatra se da niska razina kronične upale, otpuštanje bakterijskih toksina i aktivacija proupalnih medijatora u krvi uzrokuju pogoršanje kronične sistemske bolesti. Svrha našega istraživanja bila je istražiti moguću povezanost parodontne bolesti, upalnih citokina i kronične bubrežne bolesti. U ovo presječno istraživanje uključili smo ukupno 80 ispitanika podijeljenih u dvije skupine. U prvu skupinu uključili smo ispitanike s kroničnom bubrežnom bolešću III. i IV. stadija, a u drugu ispitanike s kroničnom bubrežnom bolešću V. stadija koji su na hemodijalizi. Usporedili smo parodontni status među skupinama ispitanika, kao i serumske vrijednosti interleukina 6 (IL-6), interleukina 17A i faktora tumorske nekroze $\alpha$. Rezultati su pokazali da nema značajnije razlike u parodontnom statusu među skupinama ispitanika, ali su vrijednosti IL-6 bile značajno veće u skupini ispitanika na hemodijalizi te su također bile povezane s lošijim parodontnim statusom kod ove skupine bolesnika.

Ključne riječi: Parodontna bolest; Kronična bubrežna bolest; Hemodijaliza; Upala; Citokini 